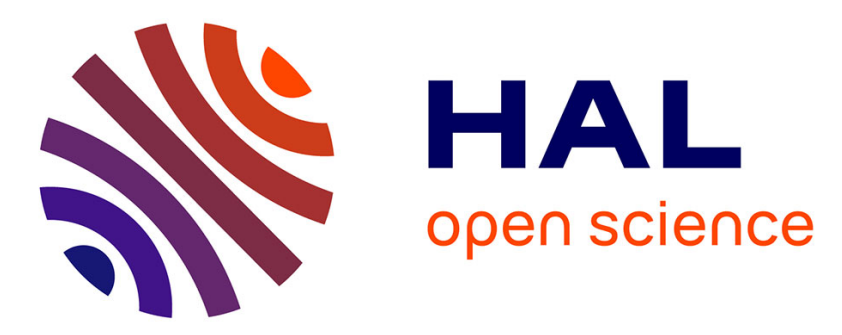

\title{
Molecular basis of film formation from a soybean protein: Comparison between the conformation of glycinin in aqueous solution and in films
}

\author{
M. Subirade, I. Kelly, M. Pezolet
}

\section{- To cite this version:}

M. Subirade, I. Kelly, M. Pezolet. Molecular basis of film formation from a soybean protein: Comparison between the conformation of glycinin in aqueous solution and in films. International Journal of Biological Macromolecules, 1998, 23, pp.241-249. hal-02687423

HAL Id: hal-02687423

https://hal.inrae.fr/hal-02687423

Submitted on 1 Jun 2020

HAL is a multi-disciplinary open access archive for the deposit and dissemination of scientific research documents, whether they are published or not. The documents may come from teaching and research institutions in France or abroad, or from public or private research centers.
L'archive ouverte pluridisciplinaire HAL, est destinée au dépôt et à la diffusion de documents scientifiques de niveau recherche, publiés ou non, émanant des établissements d'enseignement et de recherche français ou étrangers, des laboratoires publics ou privés. 


\title{
Inventaire

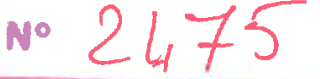

International Journal of Biological Macromolecules 23 (1998) 241-249

\section{Molecular basis of film formation from a soybean protein: comparison between the conformation of glycinin in aqueous solution and in films}

\author{
Muriel Subirade a,b,*, Isabelle Kelly a , Jacques Guéguen ${ }^{\mathrm{b}}$, Michel Pézolet ${ }^{\mathrm{a}}$ \\ a Centre de Recherches en Sciences et Ingénierie des Macromolécules, Département de Chimie, Université Laval, Laval, Qué. G1K 7P4, Canada \\ ${ }^{\mathrm{b}}$ Laboratoire de Biochimie et Technologie des Protéines, Institut National de la Recherche Agronomique, rue de la Géraudière, B.P. 1627,
} 44316 Nantes cédex 03, France

Received 16 December 1997; received in revised form 14 March 1998; accepted 2 June 1998

\begin{abstract}
Fourier transform infrared spectroscopy has been used to investigate the conformational changes of glycinin, a major storage protein of soybean seeds, upon film-forming. The results show that the secondary structure of glycinin is mainly composed of a $\beta$-sheet (48\%) and unordered (49\%) structures. The amide I band of glycinin in film-forming conditions, i.e. in alkaline media and in the presence of plasticizing agent, reveals the conversion of $18 \%$ of the secondary structure of the protein from the $\beta$-sheet $(6 \%)$ and random coil $(12 \%)$ to the $\alpha$-helical conformation due to the helicogenic effect of the ethylene glycol used as the plasticizing agent. Conformational changes also occur upon the film-forming process leading to the formation of intermolecular hydrogenbonded $\beta$-sheet structures. Results obtained from other plant families indicate that, whatever the origin and conformation of protein, formation of films leads to the appearance of intermolecular hydrogen-bonded $\beta$-sheet structures, suggesting that this type of structure might be essential for the network formation in films. Thus, it is hypothesized that, in the film state, intermolecular hydrogen bonding between segments of $\beta$-sheet may act as junction zones in the film network. This study reveals for the first time that there is a close relationship between the conformation of proteins and the mechanical properties of films. (C) 1998 Elsevier Science B.V. All rights reserved.
\end{abstract}

Keywords: Film; Glycinin; Structure; Fourier transform infrared spectroscopy; Vegetable proteins; Structure-function relationships

\section{Introduction}

During the last decade, the loss of landfile space and a change in the public perception of acceptable waste, waste reduction and waste elimination, have increased interest in biodegradable plastics. Recent research efforts to develop polymeric alternatives to petroleum-based products have centered

\footnotetext{
* Corresponding author. Present address: Centre de recherche STELA, Pavillon Paul-Comtois, Université Laval, Laval, Qué. G1K 7P4, Canada. Tel.: + 14186562131 ext. 4278; fax: + 1418 6563353; e-mail: Muriel.Subirade@aln.ulaval.ca
}

on biopolymers as starting materials. Several substances derived from biological materials, such as proteins and starch, have drawn attention for their film-forming ability making them good candidates as ingredients in package products and edible films [1-5].

Glycinin is one of the major globulins of the soya representative of 11S-type seed proteins that are largely distributed in plants. It is made of six subunits, each consisting of a basic polypeptide $(\beta$-polypeptide) and an acidic polypeptide $(\alpha-$ polypeptide), which are connected by a single disulfide bond forming the $\alpha \beta$ subunit [6,7]. It has 
been suggested that in the glycinin molecule, six subunits are packed in two stacked hexagonal rings [6] or in two identical trigonal antiprisms stacked on top of each other and held together by hydrophilic forces, such as electrostatic and hydrogen bonds $[8,9]$, although neither model can account very well for the observed results [10]. A great deal of work has been done on functional properties of glycinin showing that it is a major functional ingredient commonly used as a gel, emulsifiant and foaming agent in technological processes [11,12]. Recently, it has been shown that glycinin is able to form films, making it a good candidate as an ingredient in package products and edible films [13-16]. These studies have shown that several factors, such as protein concentration, $\mathrm{pH}$, ionic strength, heating temperature and plasticizers affect the formation of a film from soy proteins. Therefore, it has been suggested that the glycinin film network is formed via hydrogen bonds, hydrophobic and electrostatic interactions between polypeptides. However, the structural basis of the film-forming process is, at present, not understood. No attempts have been made to determine the relationship between the extent of formation of the film network and the structure of the protein in the film and nothing is known about the molecular basis which leads to the formation of films.

The formation of films from soy globulins and other globular proteins has been described as a two-step process involving the heat denaturation of the proteins followed by surface dehydration [17]. Heating alters the three-dimensional structure of proteins, exposing functional groups - such as $\mathrm{CO}$ and $\mathrm{NH}$ of peptidic bonds, side chain amine groups and hydrophobic groups-engaged in intramolecular hydrogen bonding and electrostatic interactions in the native state which become available for intermolecular interactions $[18,19]$. Upon drying, the unfolded proteins approach each other and become linked through intermolecular interactions (through disulfide and hydrophobic interaction), leading to the formation of a network that acts as the matrix for entrapping film components such as plasticizing agents [17]. Since the formation of film occurs in denaturated conditions (alkaline conditions and heating above the denaturation temperature of the protein), it is assumed that the protein remains in the fully denaturated state in the film. However, it is quite possible that the denatured protein may undergo partial refold- ing, thus regaining some secondary structure during the film process. It is conceivable that the extent of such refolding affects the number of functional groups available for intermolecular interactions and thus the formation and stability of the film network.

In order to elucidate the molecular basis of the film formation process, we have studied, for the first time, the conformational changes of glycinin during film formation. Only a few physical methods can provide information on the structural changes of proteins that take place during the formation of precipitates or gel assemblies. Recently, circular dichroism (CD) has been used to obtain insight into the conformation of globular proteins in heat-induced gels [19]. However, the necessity of using transparent samples for $C D$ measurements [20] limits the range of application of this technique. In this work, we have used infrared spectroscopy to obtain detailed molecular information on the conformational behavior of glycinin during the film-formation process. It is now well established that infrared spectroscopy is a powerful method for the investigation of the secondary structures of proteins in solution [21$24]$ or in complex systems, such as biological [2529] or food [30-32] systems.

\section{Materials and methods}

\subsection{Purification of glycinin}

Glycinin was purified from soy seeds as previously described [15]. Briefly, defatted soybean flour was stirred in a buffer $\left(\mathrm{Na}_{2} \mathrm{~S}_{2} \mathrm{O}_{5}, \mathrm{NaOH}, \mathrm{pH}\right.$ $8,20^{\circ} \mathrm{C}$ ) for $1 \mathrm{~h}$ and centrifuged at $10000 \times g$ for $20 \mathrm{~min}$. Then the $\mathrm{pH}$ of the supernatant was adjusted to 5.5 with $\mathrm{HCl}$ and centrifuged again. The precipitate, enriched in 11S fraction (approximately $80 \%$ ), was freeze dried and ground.

\subsection{Preparation of the protein films}

Protein films were prepared as described by Kokelaar et al. [16]. Briefly, the protein solution $(13 \% \mathrm{w} / \mathrm{w})$ was dispersed with a Polytron homogenizer (20000 rpm) during $1 \mathrm{~min}$ in a glycine/ sodium hydroxide solution $(\mathrm{pH} 10)$. The plasticizer was then added (w/w plasticizer/protein ratio of 1) and the solution was dispersed again with the homogenizer during $30 \mathrm{~s}$ and centrifuged 
at low speed $(1500 \times g)$ for $30 \mathrm{~min}$ to remove entrapped air bubbles. Then, the aerated supernatant was discarded and the film-forming solution was spread on a glass plate. After a drying period of $1 \mathrm{~h}$ at $70^{\circ} \mathrm{C}$, the protein was cooled down and carefully peeled off the glass plate and stored in a box with controlled relative humidity $(60 \% \mathrm{RH})$ and temprature $\left(22^{\circ} \mathrm{C}\right)$ for 3 days.

\subsection{Infrared spectroscopy}

Infrared spectra were recorded with a Nicolet Magna 550 Fourier transform infrared spectrometer with a liquid nitrogen cooled mercury-cadmium-telluride detector. The instrument was continuously purged with dry air. For transmission measurements, protein solution $(8 \%, \mathrm{w} / \mathrm{v})$ was placed in a thermostated home-made closed cell consisting of two $\mathrm{BaF}_{2}$ windows separated by a 6 $\mu \mathrm{m}$ mylar spacer. For each spectrum, a total of 250 scans were collected at $2 \mathrm{~cm}^{-1}$ resolution. The algorithm of Dousseau et al. [33] was used to substract the spectrum of the aqueous buffer from the corresponding spectrum of the protein solution. Spectra of films were obtained by attenuated total reflection (ATR) using a single reflection accessory (Harrick Scientific, USA) fitted with a zinc selenide prism. All data manipulations were performed with the Spectra Calc sofware (Galactic Industries, Salem, NH). Fourier deconvolution was carried out using the method of Griffiths and Pariente [34] with a narrowing parameter, $\gamma$, of 4.5 and an apodization filter of 0.19 . These parameters were chosen in order to obtain optimum resolution without introducing significant sidelobes in the $1690-1720 \mathrm{~cm}^{-1}$ region where there is no protein band.

\section{Results and discussion}

\subsection{Conformational behavior of glycinin in film-forming conditions}

Fig. 1 displays the original (Fig. 1A) and deconvolved (Fig. 1B) infrared spectra of glycinin in the amide I band region $\left(1590-1720 \mathrm{~cm}^{-1}\right)$ as a function of the film-forming conditions, i.e in alkaline conditions and in the presence of the ethylene glycol. This region, which is mainly due to the $\mathrm{C}=\mathrm{O}$ stretching vibration and to a small extent to $\mathrm{C}-\mathrm{N}$ stretching vibration of the peptide bonds, is sensitive to the secondary structure of proteins [21]. Fig. 1 shows the infrared spectrum of the soy protein recorded at room temperature and at $\mathrm{pH} 7$ after correction for the spectral contribution of the water bending vibration according to the method of Dousseau et al. [33]. In the original spectrum, the amide I band appears as a broad band with an absorbance maximum around $1648 \mathrm{~cm}^{-1}$. This band is composed of several overlapping components due to various protein segments with different secondary structures $[35,36]$. Deconvolution of the amide bands reveals that the amide $I$ band is composed of at least five components at 1615 , 1638,1655 and $1687 \mathrm{~cm}^{-1}$, and a shoulder one at $1670 \mathrm{~cm}^{-1}$. The assignment of these bands, based on previous studies of proteins by vibrational spectroscopy, can be summarized as follows: the two bands at 1638 and $1687 \mathrm{~cm}^{-1}$ are highly characteristic of amide groups involved in the extended $\beta$-sheet structure [21-23,37] while the band at $1655 \mathrm{~cm}^{-1}$ results from either the $\alpha$-helix or random coil structures. The $1670 \mathrm{~cm}^{-1}$ component can be assigned to the presence of $\beta$-turns [30] and the weak shoulder at $1615 \mathrm{~cm}^{-1}$ arises

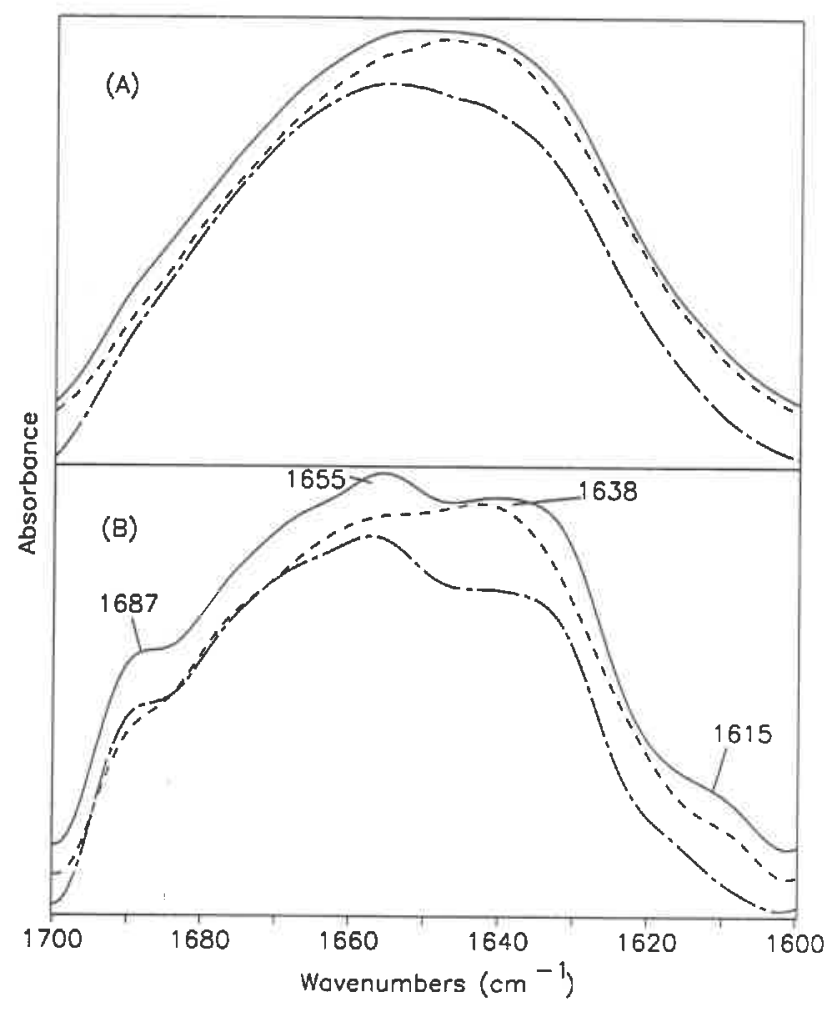

Fig. 1. Original (A) and deconvolved (B) infrared spectra of soy glycinin in $(-)$ aqueous solution $(\mathrm{pH} 7),(--)$ alkaline conditions ( $\mathrm{pH} \mathrm{10)}$ and (-- - - - ) film-forming conditions ( $\mathrm{pH} 10$ and presence of ethylene glycol). 
from intermolecular $\beta$-sheets due to protein aggregation [38]. This qualitative analysis is in good agreement with previous data [39].

The various methods for the quantitative determination of the secondary structure of proteins in solution and their respective merits and drawbacks have recently been reviewed $[22,23]$. In this work, we have used the method of Dousseau and Pézolet [40] to quantify the secondary structure content of glycinin in aqueous solution since this method provides low prediction errors. The results obtained reveal that the native protein is composed of $48 \% \beta$-sheets, $49 \%$ unordered structure or $\beta$ turns, and of only $3 \% \alpha$-helices. These results are in good agreement with those obtained previously by $C D[19,41]$ revealing that glycinin belongs to the class of $\beta$-sheet proteins. This is a common feature of $11 \mathrm{~S}$ globulins isolated from other legume seeds $[42,24]$. Our results therefore confirm that the conformation of glycinin is mainly composed of $\beta$-sheet structure. Moreover, they also clearly demonstrate that glycinin contains other secondary structures, such as turns, and provide the first direct identification of the different components.

Since film formation occured in alkaline conditions, we have recorded the infrared spectrum of glycinin at $\mathrm{pH} 10$. It has been known for some time that glycinin undergoes several conformational and/or structural changes as a function of $\mathrm{pH}$ due to aggregation and disaggregation processes [12]. In order to detect and characterize these conformational changes, the infrared spectrum of glycinin solution at $\mathrm{pH} 10$ has been recorded and is shown in Fig. 1. As seen in this figure, alkalination of glycinin solution has a marked effect on the infrared spectrum of the protein. The absobance maximum of the original amide I band is shifted from $1648 \mathrm{~cm}^{-1}$ in the spectrum recorded at $\mathrm{pH} 7$ to $1641 \mathrm{~cm}^{-1}$ in the spectrum obtained at $\mathrm{pH} 10$. These changes are more clearly observed in the deconvolved spectra. The spectrum shows a shift in the band observed at $1638 \mathrm{~cm}^{-1}$ at $\mathrm{pH} 7$ to $1641 \mathrm{~cm}^{-1}$ at $\mathrm{pH} 10$. This band cannot be assigned unambiguously to $\beta$-sheet structures [43] since it has previously been assigned to 'open loops' [44] and random coil structure [25]. However, since the increase in intensity of the band at $1641 \mathrm{~cm}^{-1}$ is accompanied by a concomittant decrease of the bands at 1637 and $1687 \mathrm{~cm}^{-1}$ due to the $\beta$-sheet and that at $1655 \mathrm{~cm}^{-1}$ characteristic of the $\alpha$-helical confor- mation, this suggests that the band located at 1641 $\mathrm{cm}^{-1}$ is probably due to unordered structure. This is confirmed by quantitative analysis using the method of Dousseau and Pézolet [40] which reveals an increase of the unordered structure content of about $5 \%$. These results are in agreement with those obtained by nuclear magnetic resonance (NMR) spectroscopy [45] showing that alkaline conditions lead to the partial denaturation of glycinin. This can explain the fact that even at $\mathrm{pH} 12$ some of the polypeptide chains of the protein may still maintain a hydrophobic core [46], preventing some of the disulfide bonds from being cleaved [47]. Furthermore, it has been shown previously that alkaline conditions break step by step the oligomeric structure $(\alpha \beta)_{6}$ of glycinin into the $(\alpha \beta)_{3}$ intermediate and its $(\alpha \beta)$ subunits, which sediment around $7 \mathrm{~S}$ and $3 \mathrm{~S}$, respectively [11]. From the infrared spectroscopy results, it is clear that the disruption of the quaternary structure of glycinin is accompanied by partial denaturation of the protein.

In addition to the film-forming protein, a major component of films is the plasticizer. The addition of a plasticizing agent to the film is required to overcome film brittleness caused by extensive intermolecular interactions [48]. Plasticizers reduce these forces and increase the mobility of protein chains, thereby improving flexibility and extensibility of the film [2]. Polyols, such as glycerol, ethylene glycol and sorbitol, are good plasticizers due to their ability to reduce internal hydrogen bonding while increasing intermolecular spacing. Because of their ability to affect the conformation of glycinin, the effect of plasticizer on the secondary structure of glycinin has been examined. Fig. 1 shows the infrared spectrum of an alkaline solution of glycinin in the presence of ethylene glycol used as the plasticizing agent. This spectrum displays a shift in the band observed at $1641 \mathrm{~cm}^{-1}$ in the absence of the plasticizing agent to 1638 $\mathrm{cm}^{-1}$ in the presence of ethylene glycol. Moreover, this spectrum shows a marked increase in the $1655 \mathrm{~cm}^{-1}$ band relative to that located at 1638 $\mathrm{cm}^{-1}$. This result suggest that the plasticizing agent leads to an increase of the $\alpha$-helical content of the protein. This is due to the conversion of $18 \%$ of the secondary structure contents of the protein from the $\beta$-sheet $(6 \%)$ and random coil $(12 \%)$ to the $\alpha$-helical conformation. This helicogenic effect is a comon feature of most alcohols used as solvents for proteins [49]. It has been 
shown for some time that hydroalcoholic mixtures, generally used to study proteins at low temperatures [50] or to mimic the membrane environment [51], induce helical secondary structures within polypeptide chains. This effect has been attributed to a combination of two factors: the high dipole moment of alcohols induces the disruption of the internal hydrogen bonds of the peptide groups by competition of the alcohol $\mathrm{OH}$ group and the peptide $\mathrm{N}-\mathrm{H}$ group to hydrogen bond to the amide $\mathrm{C}=\mathrm{O}$ and the low dielectric constant of alcohols that is able to perturb the structure of protein by reducing the hydrophobic effect. This last effect promotes unfolding of the protein and refolding into an $\alpha$-helical conformation which is the most energetically stable conformation even in the case of proteins known to have a non-helical native structure, such as $\beta$-lactoglobulin, concanavalin A or $\beta$-casein [51]. Compared to most alcohols, ethylene glycol has a high enough dipole moment (2.2 Debye) to disrupt intramolecular hydrogen bonds and a low enough dielectric constant (38.6, which is about half that of water) to reduce the hydrophobic effect and to induce the formation of $\alpha$-helices in glycinin.

In conclusion, our infrared results show that film-forming conditions, i.e. alkaline conditions and the presence of plasticizers, induce glycinin structural changes consistent with a reorganization of the secondary structure of the protein in which the $\alpha$-helical content is more important. Moreover, they clearly demonstrate the potential of Fourier transform infrared (FTIR) spectroscopy to determine conformational changes of a globular protein as a function of environmental conditions.

\subsection{Conformational behavior of glycinin during the film-forming process}

Having characterized the structural change induced by alkaline conditions and the presence of plasticizer, we have also addressed the question of film process-induced conformational changes of glycinin. Since the first step of the film process corresponds to the gelation of protein, we examined conformational changes of glycinin upon heating the protein solution above the denaturation temperature of the protein, then upon cooling the solution to $20^{\circ} \mathrm{C}$.

Fig. 2 shows the deconvolved infrared spectrum of the amide I region for a filmogen solution of glycinin obtained after a heating time of $1 \mathrm{~h}$ at a

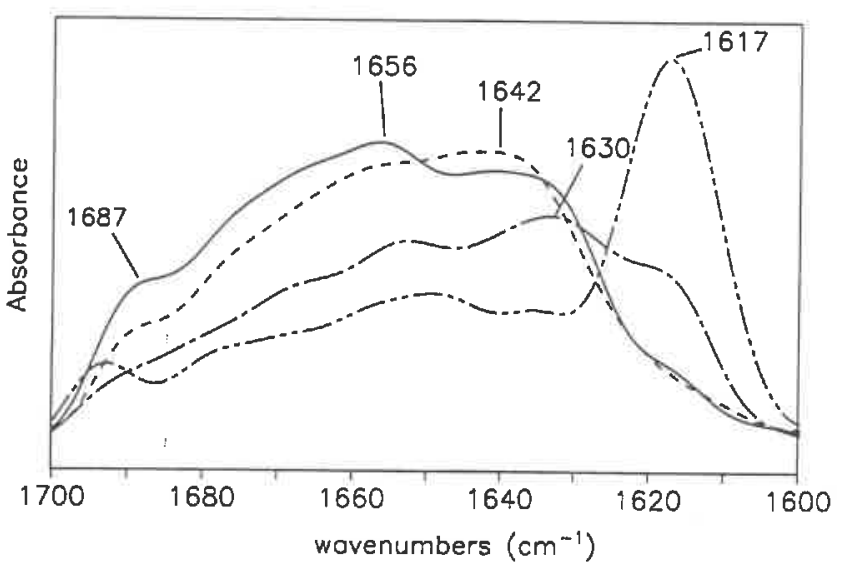

Fig. 2. Deconvolved infrared spectra of glycinin in $(-)$ the film-forming conditions ( $\mathrm{pH} 10$ and ethylene glycol), (-- ) after heating for $1 \mathrm{~h}$ at $70^{\circ} \mathrm{C},(--\cdots--)$ after cooling to $20^{\circ} \mathrm{C}$ and $\left(--_{-}--_{-}\right)$in the film state.

temperature of $70^{\circ} \mathrm{C}$. A comparison of this spectrum with that recorded at $20^{\circ} \mathrm{C}$ before thermal treatment (Fig. 2) indicates that the temperature has an important effect on the secondary structure of glycinin. On heat treatment, the band observed at $1638 \mathrm{~cm}^{-1}$ shifts to $1642 \mathrm{~cm}^{-1}$ and appears to become broader at $70^{\circ} \mathrm{C}$, suggesting that thermal treatment results in extensive denaturation of the secondary structure of soy $11 \mathrm{~S}$. This unfolding is accompanied by a decrease in the intensity of the band located at $1655 \mathrm{~cm}^{-1}$, indicating a decrease in $\alpha$-helices content. Moreover, a striking feature of this spectrum is that it is practically identical with the spectrum recorded at $\mathrm{pH} 10$ (in the absence of plasticizer) and at room temperature (see Fig. 1B). Since pH 10 represents the first stage of the alkaline denaturation and $70^{\circ} \mathrm{C}$ the first stage of the thermal denaturation [11], our results suggest that the thermal denaturation proceeds via the same intermediate state as the alkaline denaturation.

The heat-induced structural changes of glycinin observed in this study are consistent with previous NMR results [52] which show that heat treatment induces an increase of glycinin molecular motion and protein unfolding, and with CD data [19] which show a decrease of the $\alpha$-helical and $\beta$-sheet structures at the expense of the random coil structure. Although similar results have been reported in the case of $\beta$-conglycinin, another globular protein from soy [19], most studies reported so far on the thermal denaturation of globular proteins such as $\beta$-lactoglobulin [53], bovine serum albumin [54], ovalbumin [55] or $\alpha$-lactalbumin, reveal 
the appearence of new $\beta$-sheets during heat denaturation. In the case of glycinin, new $\beta$-sheets appear only upon cooling the solution to $20^{\circ} \mathrm{C}$ as shown from Fig. 2. The main spectral effect is a marked increase in intensity of the $\beta$-sheet band at $1630 \mathrm{~cm}^{-1}$. The frequency of this band (1630 $\mathrm{cm}^{-1}$ ) is much lower than that we assigned to the $\beta$-sheet conformation $\left(1637-1639 \mathrm{~cm}^{-1}\right)$, suggesting an increase in hydrogen-bond strength upon cooling the solution. This treatment also induces a decrease of the intensity of the $1655 \mathrm{~cm}^{-1}$ band due to the $\alpha$-helix structure and to the appearance of a new band at $1617 \mathrm{~cm}^{-1}$. The latter is assigned to the formation of an intermolecular hydrogenbonded $\beta$-sheet structure since it occurs readily upon aggregation of proteins [56] or polypeptides [38]. These infrared results show that soy $11 \mathrm{~S}$ globulin undergoes partial refolding during the cooling regime of the gelation process. Previous $\mathrm{CD}$ results [57] have also shown that glycinin regains secondary structures during the cooling phase of the thermal gelation. These authors showed that the extent of such refolding plays a critical role in the formation and stability of the gel network by modifying the number of functional groups available for intermolecular interactions. They suggested that, by controlling the extent of refolding of the protein during the cooling regime, it is possible to improve the gelation of glycinin [57]. Our results show that the mechanism of thermal gelation of glycinin in the film-forming conditions is comparable to that proposed for other globular proteins [58] and can be summerized in a two-stage sequential process: the first phase involves heat-induced conformational changes in the protein with unfolding of some polypeptide segments followed, upon cooling, by a subsequent phase of protein-protein interactions resulting in a buildup of a network structure.

The last step of the film process consists of surface dehydration. The spectral changes which follow this phenomenom are shown in Fig. 2. As can be seen, all the amide I bands lose intensity upon dehydratation of the film excepted for the band located at $1617 \mathrm{~cm}^{-1}$ which becomes strong and sharp. These results suggest a marked reduction of $\alpha$-helical, $\beta$-sheet and unordered structures at the expense of intermolecular hydrogen-bonded $\beta$-sheet structure. Although it has not been possible to obtain quantitative results with low prediction errors on the conformation of the $11 \mathrm{~S}$ protein in the film state since the currently available meth- ods have been developed for proteins in solution [40] or for ATR measurements using deuterated protein films [25], it is clear that the protein in the film state displays a much higher content of intermolecular $\beta$-sheets and a lower content of $\alpha$-helices, $\beta$-sheets and unordered conformation compared to the protein in solution.

The formation of intermolecular $\beta$-sheets during the film formation is not unique to glycinin and seems to be a common behavior of vegetable proteins whatever their origin [59]. In Fig. 3, the infrared spectrum of glycinin in the film state is compared to those obtained from legumin, a major globulin from pea, and wheat gluten proteins. A striking characteristic of this figure is that all spectra show the band characteristic of intermolecular $\beta$-structures located at $1618 \mathrm{~cm}^{-1}$. These similarities could be due to similar secondary structures of these protein molecules. However, if legumin belongs to the same family of glycinin and contains mainly $\beta$-sheet and aperiodic structures in the native state [24], whole gluten proteins exhibit a different secondary structure [30] and contain approximately equal amounts of $\alpha$-helices (31\%), $\beta$-sheets $(28 \%)$ and $\beta$-turns $(27 \%)$. These results suggest that $\beta$-sheet structures might be essential for protein-protein interactions and network formation in films formed from vegetable proteins, whatever their origin and conformation. These results support the idea that intermolecular hydrogen-bonding interactions between $\beta$-sheets may act as junction zones and thus stabilize the film network. However, it should be pointed out that the spectrum of wheat proteins presents more regular secondary structure than those of the other

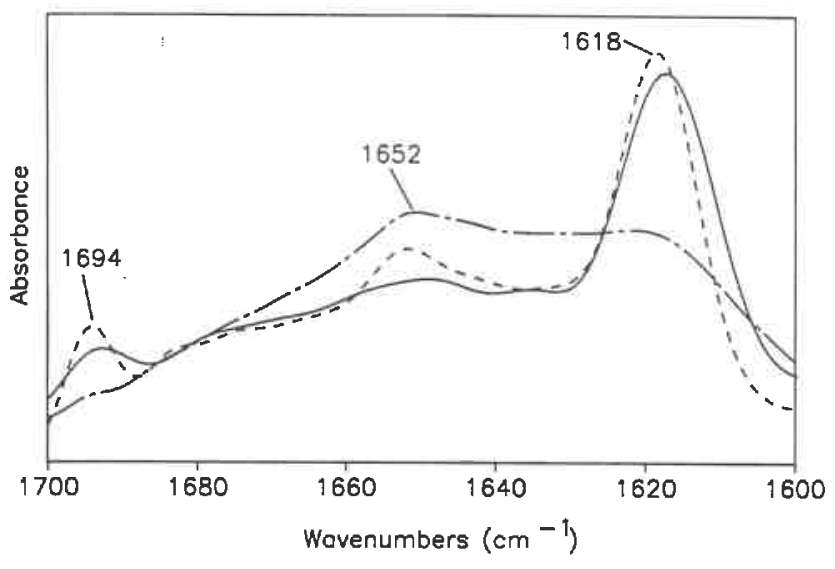

Fig. 3. Deconvolved infrared spectra of $(-)$ soy glycinin, $(--)$ pea legumin and $(-------)$ wheat gluten proteins, in the film state. 


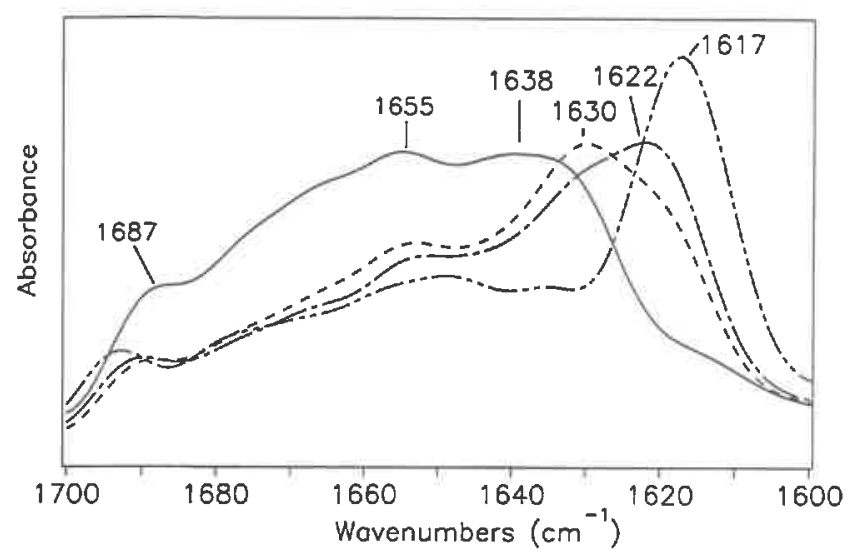

Fig. 4. Infrared spectra of glycinin in $(-)$ aqueous solution and in the films prepared from (- - ) glycerol, $\left(----_{--}\right)$ diethylene glycol and (- - - - - -) ethylene glycol.

proteins. It therefore seems that the $\alpha$-helices are partially conserved in films prepared from wheat gluten proteins.

\subsection{Effect of plasticizers on the network structure of films}

Previous studies on films of wheat gluten [48], soybean globulins [14] and whey proteins [60] have shown that the nature of plasticizers used in film formation has a great effect on their mechanical properties. Since proteins may undergo structural changes in the presence of plasticizers, the extent of denaturation and the exposure of functional groups may affect the mechanical properties of films. However, the relationship between mechanical properties of protein films and conformational changes of proteins have not yet been studied. To understand the relationship between the conformation of glycinin and the mechanical properties of films of this protein, the infrared spectra of films of glycinin obtained from different plasticizers such as glycerol, diethylene glycol and ethylene glycol, were recorded. As seen in Fig. 4, the spectra obtained show strong differences compared to the spectrum of the native protein. The main spectral difference is a sharp increase in intensity of the band due to the intermolecular $\beta$-sheet at the expense of the lower frequency bonds assigned to other strutures. In addition, there is a shift of the position of the $\beta$-sheet band with the plasticizer used. The $\beta$-sheet band observed at 1638 $\mathrm{cm}^{-1}$ in the spectrum of the protein in solution shifts to 1630,1622 and $1618 \mathrm{~cm}^{-1}$ in the film state in the presence of glycerol, diethylene glycol and ethylene glycol, respectively. A shift of this band to lower wavenumbers can be attributed to a strengthening of the hydrogen bonds between the peptide groups [61]. A previous study on the physical properties of glycinin films [16] reveals a plasticizer dependence of mechanical properties of films and shows that the young modulus of glycinin films decreases in the order ethylene glycol $>$ diethylene glycol $>$ glycerol. Close comparison of this behavior with corresponding changes in position of the infrared amide I band suggests for the first time that a close relationship exists between conformation of the protein in the film and the mechanical properties of these films.

On the other hand, the mechanical properties of macromolecules are not strongly influenced only by the structure of the material but also by molecular orientation induced by the forming process. In order to check for any preferred alignment of the $\beta$-sheet structure with respect to the film, polarized ATR-FTIR spectra of

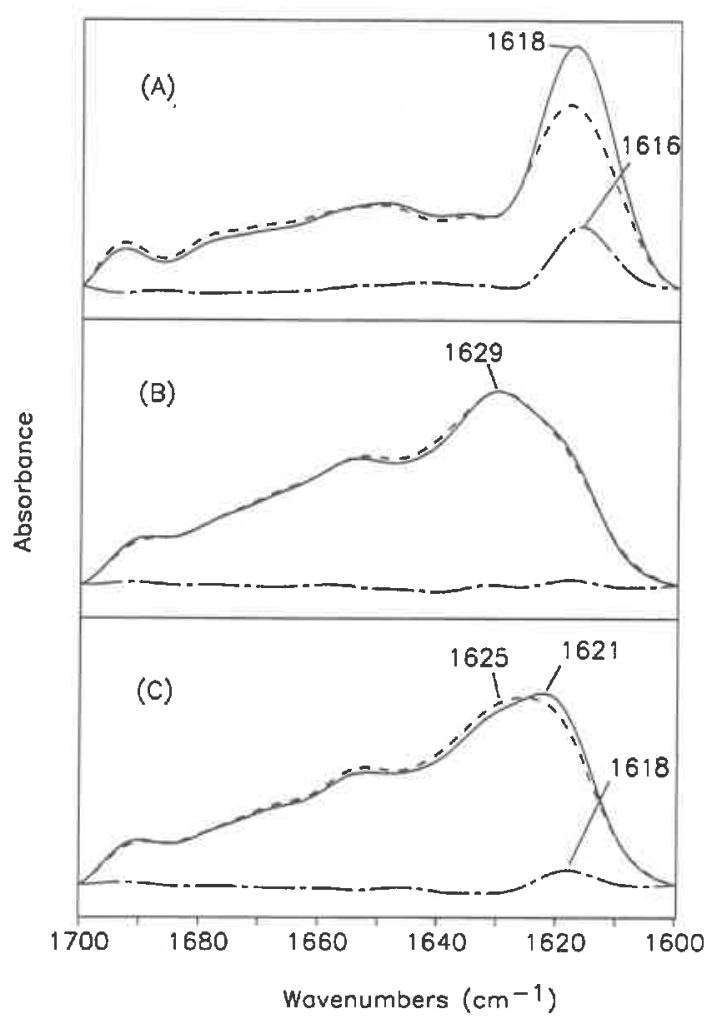

Fig. 5. ATR infrared spectra recorded with the incident radiation polarized parallel (-) and perpendicular (- - ) to the films prepared from (A) ethylene glycol, (B) diethylene glycol and (C) glycerol. The difference between the parallel and perpendicular spectra is also shown $(-------)$. 
glycinin films have been recorded. Fig. 5 shows the difference spectra between the spectra recorded using the infrared radiation polarized parallel and perpendicular as a function of the plasticizer used for the film preparation. These spectra show clearly that the amide I band is strongly polarized in the case of the film obtained from ethylene glycol as opposed to those obtained from glycerol and diethylene glycol, suggesting that the $\beta$-sheets are highly oriented in the plane of the film obtained from ethylene glycol. One can suppose that this orientation is favored by ethylene glycol which can act as a bridge between the polypeptide chain increasing the strength of bonds and shifting the $\beta$-sheet band position to lower wavenumbers. Ethylene glycol is a relatively small hydrophilic molecule that could be easily inserted between protein chains and established hydrogen bonds with functional groups of glycinin. On the other hand, this behavior may be due to a more complete unfolding of the protein upon the film process in the presence of ethylene glycol which allows a closer alignment of polypeptide chains with the formation of much stronger hydrogen bonds. In the case of other plasticizers, the presence of residual secondary structures (indicated by the bands at around $1650 \mathrm{~cm}^{-1}$ ) prevents such close alignment.

\section{Conclusion}

FTIR spectroscopy has been used in the present study to investigate the change in the conformation of glycinin during the film-forming process. As expected, this technique provides detailed information about the molecular structure of glycinin and can offer new insight into the protein-protein network. The results suggest that the hydrogen-bonded intermolecular $\beta$-sheet structure is essential for protein-protein interactions and network formation in the film obtained from vegetable proteins. Close comparison between the frequency of $\beta$-bands and mechanical properties of films reveals a relationship between conformation of the protein in the films and mechanical properties of the films. The mechanical properties are shown to not only be influenced by the structure of the protein but also by their molecular orientation.

\section{Acknowledgements}

We are grateful to Gérard Viroben for many hepful discussions and Jacky Barbot for his expert technical assistance. This research was supported by a research grant fron NATO (to MS).

\section{References}

[1] Kester JJ, Fennema OR. Food Technol 1986;40:47.

[2] Guilbert S. In: Mathlouthi M, editor. Food Packaging and Preservation. New York: Elsevier, 1986, p. 371.

[3] Cuq B, Gontard N, Guilbert S. Cereal Chem 1998;75(1):1.

[4] Krochta JM, De Mulder-Jonhston C. Food Technol 1997;51:61.

[5] Krotchta JM. In: Damodaran S, Paraf A, editors. Food Protein and their Applications. New York: Marcel Dekker, 1997, p. 529.

[6] Badley RA, Atkinson D, Hauser H, Oldani D, Green JP, Stubbs JM. Biochim Biophys Acta 1975;412:214.

[7] Nielson NC. In: Altschul AM, Wilcke HL, editors. New Protein Foods. Orlando, FL: Academic Press, 1985, Vol. 5, p. 27.

[8] Plietz P, Zirwer D, Schelsier B, Gast K, Damashung G. Biochim Biophys Acta 1984;784:140.

[9] Plietz P, Damaschun G. Stud. Biophys. 1986;116:153.

[10] Miles MJ, Morris V, Wright DJ, Bacon JR. Biochim Biophys Acta 1985;827:119.

[11] Peng IC, Quass DW, Dayton WR, Allen CE. Cereal Chem 1984;61:480.

[12] Kinsella JE. J Am Oil Chem Soc 1979;56:242.

[13] Brandenburg AH, Weller CL, Testin RFJ. Food Sci 1993;58:1086.

[14] Gennadios A, Brandenburg AH, Weller CL, Testin RF. J Agric Food Chem 1993;41:1835.

[15] Kokelaar JJ, Lefebvre J, Guéguen J. Film forming properties of soy proteins (11S). I. Effect of plasticizer, $\mathrm{pH}$ and heating procedure on mechanical film properties. Submitted.

[16] Kokelaar JJ, Viroben G, Lefebvre J, Guéguen J. Film forming properties of soy proteins (11S).II-Effet of plasticizer, $\mathrm{pH}$ and heating procedure on mechanical film properties. Submitted.

[17] Gennadios A, Weller CL. Cereal Foods World $1991 ; 36: 1004$.

[18] Damodaran S. In: Harwalkar VR, Ma CY, editors. Thermal Analysis Foods. New York: Elsevier, 1994, p. 1.

[19] Wang CH, Damodaran J. Agric. Food Chem. 1991;39:433.

[20] Woody RW. Circular dichroism of peptides. In: Hruby V, editor. The Peptides. San Diego, CA: Academic Press, 1985.

[21] Byler DM, Susi H. Biopolymers 1986;25:469.

[22] Arrondo JLR, Muga A, Castresana J, Goni FM. Prog Biophys Mol Biol 1993;59:23.

[23] Surewicz WK, Mantsch HH, Chapman D. Biochemistry 1993;32:389 
[24] Subirade M, Gueguen J, Pézolet M. Biochim Biophys Acta 1994;1205:239.

[25] Goormaghtigh E, Cabiaux V, Ruysschaert JM. Eur J Biochem 1990;193:409.

[26] Goormaghtigh E, Vigneron L, Scarborough GA, Ruysschaert JM. J Biol Chem 1994;269:27409.

[27] Challou N, Goormaghtigh E, Cabiaux V, Conrath K, Ruysschaert JM. Biochemistry 1994;33:6902.

[28] Tatulian SA, Hinterdorfer P, Baber G, Tamm LK. EMBO J 1995; 14:5514.

[29] Subirade M, Salesse C, Marion D, Pézolet M. Biophys J 1995;69:974.

[30] Pézolet M, Bonenfant S, Dousseau F, Popineau Y. FEBS Lett 1992;299:247.

[31] Popineau Y, Bonenfant S, Cornec M, Pézolet M. J Cereal Sci 1994;20:15.

[32] Belton PS, Colquhoun GA, Wellner N, Fiel JM, Shewry PR, Tatham AS. Int J Biol Macromol 1995;17:74.

[33] Dousseau F, Therrien M, Pezolet M. Appl Spectrosc 1989;43:538.

[34] Griffiths PR, Pariente GL. Trends Anal Chem 1986:5:209.

[35] Surewicz KW, Mantsch HH. Biochim Biophys Acta 1988;952:115.

[36] Goormaghtigh E, Cabiaux V, Ruysschaert JM. In: Hilderson HJ, Ralston GB, editors. Subcellular Biochemistry, Vol. 23. 1994, p. 329.

[37] Surewicz WK, Leddy JJ, Mantsch HH. Biochemistry 1990;29:8106.

[38] Carrier D, Mantsch HH, Wong PTT. Biopolymers 1990;29:837.

[39] Dev SB, Keller JT, Rha CK. Biochim Biophys Acta 1988;957:272.

[40] Dousseau F, Pézolet M. Biochemistry 1990;29:8771.

[41] Sureshchandra BR, Appu Rao AG, Narasinga Rao MS. J Agric Food Chem 1987;35:244.

[42] Zirwer D, Gast K, Welfle H, Schlesier B, Schwenke KD. Int J Biol Macromol 1985;7:105.
[43] Dong A, Huang P, Caughey WS. Biochemistry 1990;29:3303.

[44] Arrondo JLR, Castresana J, Valpuesta JM, Goni FM. Biochemistry 1994;33:11650.

[45] Kakalis LT, Baianu IC. J Agric Food Chem 1989;37:1222.

[46] Ishimo K, Okamoto S. Cereals Chem 1975;52:9.

[47] Draper M, Catsimpoolas N. Cereal Chem 1978;55:16.

[48] Gontard N, Guilbert S, Cuq JLJ. Food Sci 1993;58:206.

[49] Nelson JW, Kallenbach NR. Biochemistry 1989;28:5256.

[50] Douzou P. Cryobiochemistry, an Introduction. London: Academic Press, 1977.

[51] Jackson M, Manstch HH. Biochim Biophys Acta 1992;1118:139.

[52] Fisher MS, Marshall WE, Marshall HP. J Agric Food Chem 1990;38:957.

[53] Matsuura JE, Manning MC. J Agric Food Chem 1994;42:1650.

[54] Boye JI, Alli I, Ismail AA. J Agric Food Chem 1996;44:996.

[55] Herald JH, Smith DM. J Agric Food Chem 1992;40:1737.

[56] Muga A, Surewicz WK, Wong PTT, Mantsch HH, Singh VK, Shinohara T. Biochemistry 1990;29:2925.

[57] Damodaran SJ. Agric Food Chem 1988;36:262.

[58] Ziegler GR, Foegeding EA. Adv Food Nutr Res 1990;34:203.

[59] Subirade M, Kelly I, Barbot J, Viroben G, Guéguen J, Pézolet M. Conformation of vegetable proteins - comparison between solution and film states as determined by infrared spectroscopy. In: Conference on Plant Proteins from European Crops, 25-27 November 1996, Nantes, France, in press.

[60] McHugh TH, Krochta JM. J Agric Food Chem 1994;42:841.

[61] Krimm S, Bandekar J. Biochemistry 1986;28:5256. 
